\title{
Pensar o mundo
}

Lugar de diálogos por excelência, o carnaval vem ampliando suas fronteiras acadêmicas, mostrando-se eixo privilegiado para pensar as culturas no espaço e no tempo. Já vão longe os dias de penúria com relação a pesquisas sobre o tema. Inicialmente reduzidos a descrições e relatos envolvendo aspectos históricos ou curiosos, os estudos carnavalescos acabaram atraindo a atenção de diferentes áreas do conhecimento. As redes de interesses articuladas em diferentes carnavais apresentam-se, desse modo, como lócus privilegiado para a reflexão sobre as sociedades em sua complexidade. Não é de espantar, portanto, a amplitude de lugares abordados no presente número de Textos EscoIhidos de Cultura e Arte Populares. De Florianópolis a Bogotá, de Lazarin (Portugal) a Cachoeira (Bahia), passando por São Luís, Belém, Teresina, João Pessoa e Rio de Janeiro, os artigos aqui reunidos traçam amplo painel não só em termos de localizações, mas, principalmente, de multiplicidade de enfoques que vão da geografia às artes visuais e cênicas, da filosofia à antropologia, da história à sociologia, à música, à comunicação social e à história da arte. Exemplo marcante do conceito amplo de cultura popular que adotamos nesta publicação, o carnaval afirmou-se como objeto capaz de conter diferentes formas de pensar o mundo. Nossa revista orgulha-se de fazer parte desse processo.

Felipe Ferreira [editor] 